\title{
Optimization of Genetic Algorithm for Implementation Designing and Modeling in Academic Scheduling
}

\author{
Tri Suratno ${ }^{\text {1) }}$, Niken Rarasati ${ }^{2)}$, Gusmanely $Z^{3)}$ \\ Mathematics Department, Fakultas Sains dan Teknologi, Universitas Jambi, \\ Indonesia \\ email: tri@unja.ac.id, nikenrarasati@unja.ac.id, gusmanelyz@unja.ac.id
}

\begin{abstract}
This research was investigated using the Genetic Algebra Method for scheduling lectures and practicums. Genetic algorithms are used to solve problems that are modeled according to evolutionary principles in biological sciences. The application of the Genetic Algebraic Method for Scheduling Lectures and Practices is expected to be further developed into a computerized system that can replace the manual lecture scheduling and practicum methods so that it can produce a more accurate schedule with existing rules in a shorter time. The results of the use of the genetic algorithm method are obtained from the results of the data which are fixed scheduling lecture data and can be recommended for lectures according to the lecture schedule obtained from the results of generating genetic algorithms
\end{abstract}

Keywords : Scheduling; Genetic Algorithms; Designing

\section{Introduction}

Scheduling lectures and practicums is one of the spearheads of the smooth learning process in each semester. The teaching and learning activities and practicum are a process that involves many parties, not only lecturers, students but spatial planning and time management. Constraints that occur in setting the lecture schedule and practicum are not simple. Some limitations when left behind in consideration, it is difficult to get an accurate schedule that is effective and optimal.

Genetic Algorithm is a solution search technique using the principle of natural selection. The Genetic Algorithm starts with selecting the settlement set. This is represented by chromosomes, which are called populations. The solution of a population is taken to form a new population, where the choice depends on the fitness value. It is expected that the new population formed is better than the previous population. This process is carried out repeatedly until it is fulfilled certain conditions.

The Jambi University Faculty of Science and Technology (FST UNJA) is one of the youngest faculties consisting of 11 study programs but the available lecture rooms are not sufficient. This has an impact on scheduling lectures and practicums that have not been optimal. As happens several different subjects are in the same room or time. With the problem of scheduling lectures and practicum at UNJA FST, it will be discussed how to optimally arrange the schedule using one of the heuristic methods, Genetic Algorithm. This algorithm is one method to solve a fairly complex problem with a fairly good solution, although the problem requires a long execution time if done manually.

Lecture scheduling and practicum is one of the important things to ensure the smooth learning and teaching process at UNJA FST. This is related to the effectiveness of the 
lecturers 'and lecturers' time division. Improvement of scheduling lectures and practicums that are more accurate and effective is one of the improvements in academic services.

During this time the scheduling of lectures and practicums is done manually so that there are often several lecture schedules and practicums that are carried out at the same time and also scheduling requires a complex mechanism and a long time. In order to get the best scheduling, a lecture scheduling and practicum system needs to be built using Genetic Algorithms that are faster, more effective and optimal so that the schedule has not been clashed. This research aim to optimize lecture scheduling and practicum at UNJA FST. The final goal of the researcher was to obtain optimal scheduling with the best combination between lecturers, subjects, room and time.

\section{Methodology}

\subsection{Genetic Algorithms}

Genetic Algorithm is an optimization algorithm of a procedure that mimics the mechanism of natural genetics. This algorithm has concepts such as natural evolution which was previously stated by one of the biology figures, Charles Darwin (1). This theory explains that each individual must be able to make adjustments to the environment around him in order to be able to survive for life.

Genetic Algorithm is applied so that the right solution is obtained for the optimal problem of one variable or many variables. Genetic Algorithms are heuristic search algorithms that are based on the mechanism of biological evolution (7). Diversity in biological evolution is a variation of chromosomes between individual organisms. These chromosome variations will affect the rate of reproduction and the level of the organism's ability to stay alive. Basically there are four conditions that greatly affect the evaluation process, namely (3):

1. The ability of an organism to reproduce;

2. The existence of a population of organisms that can reproduce;

3. Diversity of organisms in a population;

4. Differences in the ability to survive.

Genetic Algorithms consist of two operations, namely genetic operations and evolutionary operations. Genetic surgery consists of crossover operators and mutation operators. In evolutionary operations there is a selection operator. The new generation population is formed by selecting the fitness value of the parent chromosome and the fitness value of the child chromosome (offspring), and rejecting the other chromosomes so that the population size (number of chromosomes in a population) is constant (2)

The evaluation function is the link between Genetic Algorithms and problems to be solved (4). The evaluation function is the basis for carrying out the selection process. In the selection process, the chromosomes will go through an evaluation process using a measuring instrument called fitness. Individuals who are stronger (fit) will have a higher survival rate and reproductive rate when compared to individuals who are less fit. At certain times (often known as generation), the population as a whole will contain more organisms that are fit. In this algorithm, search techniques are carried out simultaneously on a number of possible solutions known as populations. Individuals in one population are called chromosome terms.

This chromosome is a solution that is still in the form of a symbol. The initial population is built randomly, while the next population is the result of chromosome evolution through an iteration called the generation term. In each generation, 
chromosomes will go through an evaluation process using a measuring instrument called a fitness function. The fitness value of a chromosome will show the quality of chromosomes in the population. The next generation is known as the child (offspring) formed from a combination of two current generation chromosomes which act as parent using a crossover operator. In addition to crossing operators, a chromosome can also be modified using mutation operators (5).

The new generation population is formed by selecting the fitness value of the parent chromosome and the fitness value of the child chromosome (offspring), and rejecting the other chromosomes so that the population size (number of chromosomes in a population) is constant. After several generations, this algorithm will converge to the best chromosomes.

\subsection{Main Components of Genetic Algorithms}

In the development cycle Genetic Algorithms look for the best solutions, there are several processes as follows :

\section{a. Encoding Techniques}

Encoding techniques here include encoding genes from chromosomes. Genes are part of chromosomes. One gene represents one variable. Genes can be represented in the form of string bits, trees, real number arrays, lists of rules, permutation elements, program elements, or other representations that can be implemented for genetic operators.

\section{b. Initialization}

Initialization is done to generate a random set of new solutions consisting of a number of chromosome strings and placed in a shelter called the population. In this stage population size (popsize) must be determined. This value states the number of individuals / chromosomes that are accommodated in the population.

\section{c. Reproduction}

Reproduction is carried out to produce offspring from individuals in the population. This set of descendants is placed in an offspring reservoir. The two genetic operators used in this process are crossover and mutation. There are many crossover and mutation methods that have been developed by researchers and are usually problem-specific and chromosome representations used.

In this stage the crossover level (crossover rate / pc) must be determined. This value states the ratio of the offspring produced by the crossover process to the size of the population so that it will produce offspring as much as pcxpopSize. The value of the mutation rate (mutation rate $/ \mathrm{pm}$ ) must also be determined. This value states the ratio of offspring produced from the process of mutation to the size of the population so that it will produce offspring as much as pmxpopSize.

\section{d. Evaluation}

Evaluation is used to calculate fitness for each chromosome. The greater the fitness, the better the chromosome is to become a potential solution.

\section{e. Selection}

Selection is done to select individuals from the population set and offspring that is maintained alive in the next generation. The greater the fitness value of a chromosome, the greater the chance to be chosen. This is done to form the next generation that is better than the current generation. Selection methods that are often used are roulette wheel, binary tournament, and elitism.

\section{f. Genetic operator}

19 IEKSAKTA: Berkala IImiah Bidang MIPA 
There are two genetic operators, namely:

1. Operators for recombination, which consists of: binary (crossover) recombination

2. Mutations, mutations of binary value

g. Determination of parameters

The parameters here are the control parameters of Genetic Algorithms, namely: population size (popsize), opportunity crossover $(\mathrm{Pc})$, and opportunity mutation $(\mathrm{Pm})$.

The value of this parameter is also determined based on the problem to be solved. There are several recommendations that can be used, including:

1. For problems that have a large enough solution, De Jong recommends the value of control parameters: $($ popsize; $\mathrm{Pc} ; \mathrm{Pm})=(50 ; 0.6 ; 0.001)$

2. If the average fitness of each generation is used as an indicator, Grefenstette recommends: (popsize; Pc; Pm) $=(30 ; 0.95 ; 0.01)$

3. If the fitness of the best individuals is monitored in each generation, the proposals are: $($ popsize; Pc; Pm $)=(80 ; 0.45 ; 0.01)$

The population size should not be smaller than 30 , for any type of problem.

\subsection{Scheduling}

Scheduling plays a very important role in the manufacturing industry and service industry (10). These problems become one of the combinatorial problems that get a lot of attention from researchers (2). Some of them prove that these problems are of type NPhard (non deterministic polynomial-time hard) or types of problems that are difficult to solve for large sizes (8).

\section{Procedure}

This research was conducted at the University of Jambi Faculty of Science and Technology which was addressed at Jalan Raya Jambi Muara Bulian KM 15 Mendalo Indah. The data used in this study are primary data regarding scheduling lectures and even semester 2017/2018 practicums obtained from the Academic Sub-Department of the Faculty of Science and Technology, Jambi University.

The devices used in this study

Tabel 1. Devices needed

\begin{tabular}{lll}
\hline \multicolumn{1}{c}{ Hardware, including } & \multicolumn{1}{c}{ Software, including } \\
\hline a. Asus Laptop & a. Operating system, Microsoft Windows 10 \\
b. Intel Core i3 Processor & b. Adobe Dreamweaver Creative Suite 5 \\
c. 4 GB Memory (RAM) & c. XAMPP-win32-1.7.3 \\
d. 500 GB Memory Capacity (Harddisk) & d. Browser, Mozilla Firefox 31.0 \\
e. Monitor 14 inch & e. PHP Programming language \\
f. and a number of other supporting hardware & f. Database MySQL \\
& g. and some other supporting software \\
\hline
\end{tabular}

As a support material that is very useful for writers to search for or collect data needed in this study, the author uses several ways, namely: literature studies on Genetic Algorithms and scheduling, observation, and interviews.

System Design

20 IEKSAKTA: Berkala IImiah Bidang MIPA 


\section{Population Formation Criteria}

Genetic Algorithms begin with a set of solutions called populations. A solution is represented by a chromosome. Some of the selected chromosomes are randomly mated and produce offspring. In this study the chromosomes used are as follows:

1. Course Code (mk)

2. Classroom (r)

3. Lecture Time $(\mathrm{w})$

4. Lecturer Code $1(\mathrm{~d} 1)$

5. Lecturer Code $2(\mathrm{~d} 2)$

6. Lecturer Code $3(\mathrm{~d} 3)$

7. Lecturer Code 4 (d4)

8. Credit (s)

\section{Scheduling Limitations}

The scheduling limits in this study include:

a. Main scheduling constraints (hard constraints)

The main limitation of scheduling is a condition or limitation that must be fulfilled to produce a course schedule that is easily done and accepted by all variables

1. Every teacher may not teach on the same day and time.

2. Each class may not enter lecture / practicum on the same day and time.

3. Each room may not be used on the same day and time.

4. Lectures must be conducted in the theory room (non-lab).

5. Lectures and practicums are conducted from Monday to Saturday

6. Lectures and practicums start from 07.30 - 17.30 WIB

7. 1 credit consists of 50 minutes

8. Teachers' time slots every day are 10 credits

9. All lectures and practicums will be vacated every Friday, starting at 11:45 WIB until 13:00 WIB. This is due to the Friday Prayer.

10. Selection of individuals using a combination of credits used, namely 2 credits and 3 credits.

11. A maximum of four lecturers are taught

b. Soft Contraints

Additional scheduling rules used in this study are:

1. Possible courses are taken by several different classes, may not be held at the same time.

2. Some courses with only one class, taken by the same class, should not be conducted at the same time.

\section{Results and Discussion}

\subsection{Display of System Implementation}

The following are the results of the implementation of the Lecture and Practicum Scheduling Optimization at UNJA FST using the Genetic Algorithm from the end-user. The appearance of the system implementation can be seen as follows:

\section{Display of System Main Page}




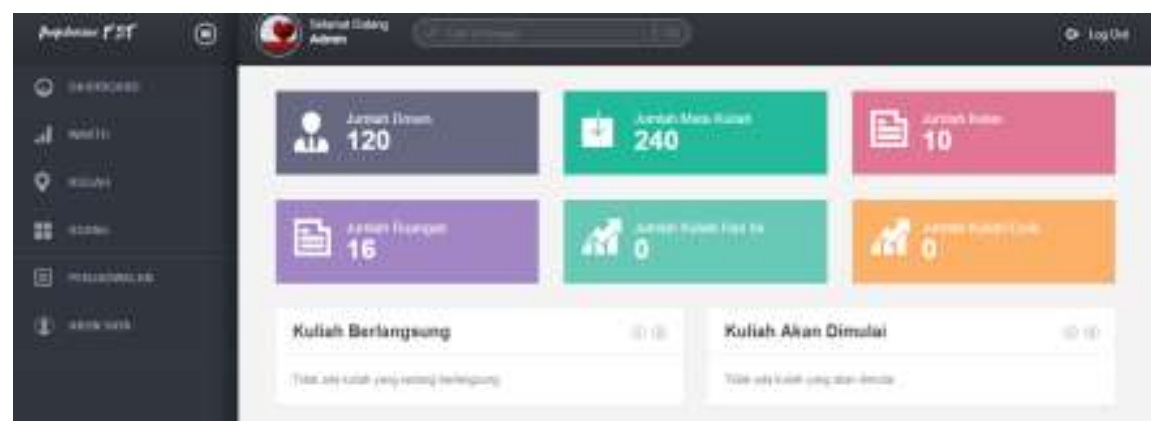

Figure 1. System Main Page

Figure 2 shows a summary of the number of lecturers, number of courses, number of classes, number of rooms available at UNJA FST that have been entered into the system.

\section{Display Menu Time}

The time menu consists of three features, namely

a. Time Data Feature

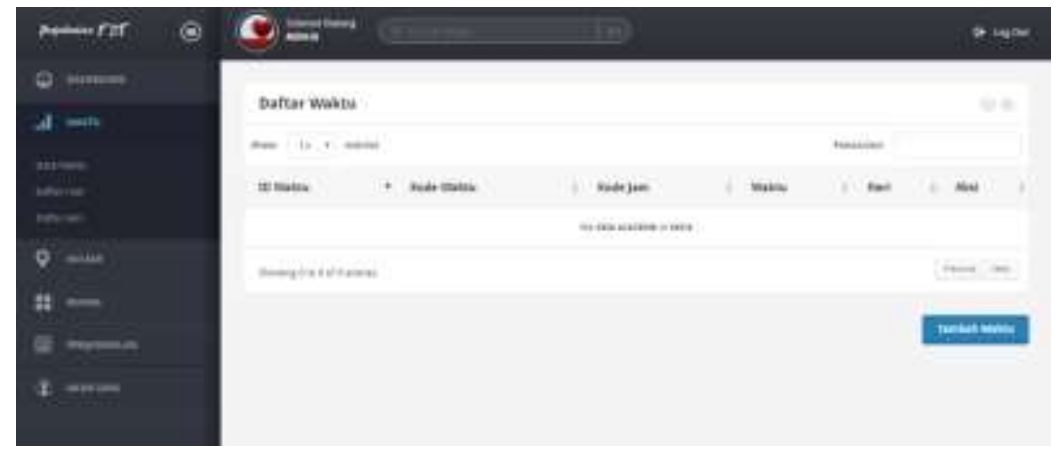

Figure 2. Time Data

This menu contains the use of time which takes place in scheduling lectures and practicums at UNJA FST.

b. Day Features

This menu contains a list of days used for lectures and practicums at the UNJA FST.

c. Clock Features

This menu contains the time allocation available for the implementation of lectures and practicum at the UNJA FST.

\section{Display the Lecture menu}

The lecture menu consists of 4 features, college data, courses, list of lecturers, class and lecture. The display scheduling menu consist 2 features, Generate Schedule Feature and Generate Results Feature. This menu is a Generate Scheduling of Lectures and Practicums Using Genetic Algorithms. In this feature Genetic Algorithms work to optimize scheduling. This feature contains steps taken in Genetic Algorithms, including:. This feature displays data results from optimization using Genetic Algorithms. The 22 IEKSAKTA: Berkala IImiah Bidang MIPA 
results data are lecture scheduling data that has been fixed and can be recommended for lectures according to the lecture schedule obtained from the results of generating Genetic Algorithms. Data results can be moved to Excel file format. Generate Results Feature. This menu is a display to display the results of scheduling optimization using the Genetic Algorithm Method.

\section{Conclusions}

This research activity was carried out by taking a case study of lecture scheduling and practicum at the Faculty of Science and Technology, Jambi University. This study aims to produce an evaluation and analysis and optimizing the scheduling of lectures and practicums at the Faculty of Science and Technology using the Genetic Algorithm Method and produce a web-based lecture scheduling and practicum system using the Algorimta Genetics Method which can be used at the Jambi University Faculty of Science and Technology to streamlining the process of scheduling lectures and practicums.

\section{Acknowledgements}

Acknowledgments the authors convey to the University of Jambi who have funded the research program from the DIPA UNJA funds in 2018 Number: SP DIPA042.01.2.400950 / 2018.

\section{References}

[1] V. Amrizal, Algoritma Genetika, Jakarta: Universitas Islam Negeri Syarif Hidayatullah, 2012

[2] A. Darmawan dan R.M. Hasibuan. (2014). Penjadwalan Mata Kuliah Menggunakan Algoritma Genetika Dengan Mempertimbangkan Team-Teaching. Simposium Nasional RAPI XIII - 2014 FT UMS- ISSN 1412-9612

[3] A. Basuki, Algoritma Genetika : Suatu Alternatif Penyelesaian Permasalahan Searching, Optimasi dan Machine Learning, Surabaya: Politeknik Elektronika Negeri Surabaya PENS-ITS, 2003

[4] Adhy, S. \& Kushartantya. 2003. Penyelesaian Masalah Job Shop menggunakan Algoritma Genetika. Jurnal Masyarakat Informatika. 1(1): 31-42.

[5] Apriani, R. 2012. Algoritma Genetika untuk Menyelesaikan Permasalahan Penjadwalan Perkuliahan dan Praktikum.Skripsi. Universitas Sumatera Utara.

[6] Bangun, P.B.J., Octarina, S. \& Virgo, G.H. 2012. Penerapan Konsep AlgoritmaGenetika untuk Penjadwalan Kegiatan Perkuliahan Semester Ganjil Kurikulum 2012 di Jurusan Matematika FMIPA UNSRI. Jurnal Penelitian Sains. 2(15): 55-59.

[7] Berlianty, I. \& Arifin, M. 2010. Teknik-Teknik Optimasi Heuristik. Graha Ilmu: Yogyakarta.

[8] Burke, E., Elliman, D.,Weare, R.1994. A Genetic Algorithm Based University Timetabling Systems. Department of Computer Science, University Nottingham.

[9] Darmawan, A, Gumilang, E.F dan Herianto, 2011, Penjadwalan mata kuliah dengan Algoritma Genetika untuk minimasi fluktuasi beban jam dosen dan mahasiswa, Prosiding: Seminar Nasional Teknik Industri, Hal: IV 36-41, 5-6 Oktober, Medan. 
[10] Pinedo. M.L. 2008. Scheduling: Theory, Algorithms, and Systems. Springer: New York. 